IRA-International Journal of Education \& Multidisciplinary Studies

ISSN 2455-2526; Vol.07, Issue 02 (2017)

Pg. no. 73-78

Institute of Research Advances

http://research-advances.org/index.php/IJEMS

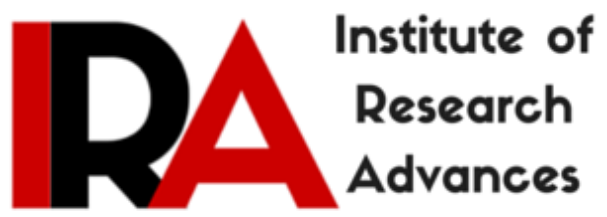

\title{
Need to Restructure Teacher Education in India with reference to Globalization and Localization
}

${ }^{1}$ Dr. Sangeeta Srivastava (M.Sc. M.Ed., MBA, Ph.D. NET),

${ }^{2}$ Dr.P.K.Srivastava (M.Com. M.A.Eco., MBA, Ph.D., D.Litt.)

Associate Professor, Teacher Education Department, D.A.V. (PG) College Muzaffarnagar. India,

${ }^{2}$ Associate Professor, Faculty of Commerce \&Business Administration, S.D.College Muzaffarnagar, India.

Type of Review: Peer Reviewed.

DOI: http://dx.doi.org/10.21013/jems.v7.n2.p2

\section{How to cite this paper:}

Srivastava, S., \& Srivastava, P. (2017). Need to Restructure Teacher Education in India with reference to Globalization and Localization. IRA International Journal of Education and

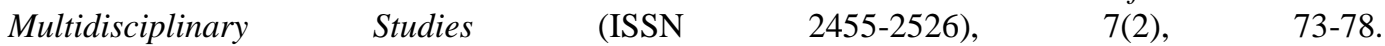
doi:http://dx.doi.org/10.21013/jems.v7.n2.p2

(c) Author.

(cc) EY-NC

This work is licensed under a Creative Commons Attribution-Non Commercial 4.0 International License subject to proper citation to the publication source of the work.

Disclaimer: The scholarly papers as reviewed and published by the Institute of Research Advances (IRA) are the views and opinions of their respective authors and are not the views or opinions of the IRA. The IRA disclaims of any harm or loss caused due to the published content to any party. 


\begin{abstract}
Globalization is a feeling that the individual is not only a member of his/her state, but a citizen of the world and subsequently teacher education should reflect this global outlook. Now the question arises: How teachers' education can be transformed from a traditional country bound training program to a new globalized teachers' education? One of the global challenges which are appearing in this context is to have a gestalt development of any country with all its special cultural identity together with globalization. Only globalization of education is inadequate without localization to pay attention towards the preserving of cultures. It should treat each unique culture and society with due respect, realizing that global education is not only learning about all innovations occurred globally, but also studying different cultures of the world and maintaining them as a cultural heritage of universe. This paper is an attempt to analyze the present position of teacher education in the context of globalization and to explore the need and ways to restructure and redefine teacher education with reference to globalization and localization. It concludes that restructuring teachers' education with reference to globalization and localization is an urgent need so that we may get such teachers who not only will possess world class knowledge but also right attitude to work and live with open mindedness, and will take them forward in global scenario for the welfare of mankind.
\end{abstract}

Key words- Restructuring, Globalization, Localization, Teacher Education

\title{
Introduction
}

Globalization is a significant factor in competitive world that integrate and mobilize cultural values of people at global level. In the age of rapid digital and technological advancements countries are now unified and transformed into one global society due to the process of globalization. In broader sense, "the term 'globalization' means combination of economies and societies through cross country flows of information, ideas, technologies, goods, services, capital, finance and people."1 Globalization is a feeling that the individual is not only a member of his/her state, but a citizen of the world. Man has feeling of love, co-operation and peace which gives birth to globalization in almost all sphere of life. In our country the concept of unity in diversity is an old cliché. Sri Aurobindo highlighted this aspect and said, "The idea of humanity as a single race of beings with a common life and a common general interest is among the most important characteristic." 2 The concept, 'Vasudhaiva Kutumbakam,' that 'the whole world is one family' was articulated here. In fact, globalization gives the reflection of our own culture which was practically visible in our ancient education system which had always embraced welfare of humanity in totality. This vary phenomenon of globalization of all highest regime of human knowledge is evident in spreading of Buddhist philosophy worldwide from India. Thanks to globalization in this modern age too, due to which the world is getting smaller in reach as well as bigger in thoughts. Responding to the serious challenges from all these impacts and transformations, our education inevitably has to change fundamentally towards a new paradigm in order to pursue a new future for our next generations and our society. The education of any nation is very much affected by the culture of that nation so in the wave of globalization the need of localization should not be ignored. Globalization and localization are two opposite processes as globalization tend to introduce uniform global practices while localization is the tendency to accommodate and modify according to local needs. Globalization is a process of designing and developing applications that function for multiple cultures while on the other hand, Localization is the process of customizing your application for a given culture and locale, both are essential for sustainable development of a country. Thus they could be accommodated within one framework to achieve unity in diversity in global perspective, where a service is provided to a global society with its localization in all aspects. 
As we all can experience that education is also being affected by the phenomenon of globalization, so is true for teacher education. The teacher education is now reforming and restructuring worldwide. This is due to emergence of international demand of teachers trained with new global structure of teacher education program. The information based teaching has been changed by learning based teaching due to the impact of globalization. A global teacher is expected not only to apply the most effective way of communication and theories of learning but also they have to respond well for the culture of that place which is further responsible for the all-round development of the child. Teacher education in India should be globalized to be able to serve global society and should be made flexible enough to be easily localized with any locale in the world so that it may serve any locale with full effectiveness. Here comes the need to restructure our teacher education with reference to globalization and localization.

\section{Purpose of Study}

The main purpose of this study is to analyze present position of teacher education in the context of globalization and to explore the needs and ways to restructure our teacher education with reference to globalization and localization to open a vast area full of opportunities for our trainee teachers and to make them more and more equipped with the trending skills to compete globally in this direction.

\section{Globalization and Education}

"Education, as a service industry, is the part of globalization process under the umbrella of General Agreement on Trade in Services (GATS). India is likely to turn into an increasingly attractive market for foreign universities and hence other nations are going to use GATS provisions to their advantage. Globalization can also have advantages, particularly for India which has a large educational system, infrastructure and diverse human capabilities." within learning systems across the world in the form of changing scenario of education system worldwide where classes have changed to smart classes and information based teaching has been changed to learning and interaction based teaching. The other immense effects observed in Indian educational sector due to globalization are increase in literacy rate and collaboration of Foreign Universities with different Indian Universities. The Indian educational system is now facing challenges of globalization through Information technology and is promoting new paradigms of developmental education with new tools and techniques such as E-learning, Flexible learning, Distance Education Programs and Overseas training etc. Chanda Rupa of IIM Bangalore has studied the implications of GATs for higher education in India. She reported that "India has received requests from several countries for opening up of services in education under service trade negotiations launched in January 2000. India has not made any offer in education service in the GATS 2000 round due to sensitive public good nature. Though several Indian students are studying in foreign universities and many foreign institutes are entering India through twinning and franchise arrangement."

In today's environment, all countries in the world are emphasizing more and more on their education services as only these services can provide individuals with a better chance of employment not only within the country but globally. In education sector, globalization refers to the transfer, adaptation, and development of values, knowledge, technology, and behavioral norms across countries and societies in different parts of the world. Reflecting the vision 2020 of planning commission of India about India's education Prof .J.S. Rajput has also visualized that "Education system of the country is already being influenced by international trends and scenarios. A large number of foreign universities are opening avenues to young persons in India to get their degrees without leaving the country. He also emphasized that the economic, social, cultural, technological changes in the national and international scene contribute to the knowledge society, information society and learning society. All these terms have now become familiar expression in the educational parlance communicating emerging global trends with far reaching implications for the growth and development of any society." $"$ Thus it is an urgent need in our 
education sector to associate with globalization through enhancing use of global networking i.e. internet, worldwide e-communication, interflow in technological, economical, social, political, cultural, and learning aspects, international alliances and competitions, international collaboration and exchange, multi-cultural integration, and use of international standards. Implications of globalization for education should include maximizing the education relevance to global development and pooling up the best intellectual resources, support and initiatives from different parts of the world for learning.

\section{Globalization and Localization of Teacher Education}

Education is undergoing constant changes under the effects of globalization and so is teachers' education. According to a UNESCO report "Teacher education is now beginning to embrace these changes. Digital learning now exists inside many classrooms in the world. Teacher education and teacher-educators will also need to exploit the possibilities of the new digital world." Globalization and technological advancements are delivering and increasing access to the world and subsequently teachers' education should reflect this global outlook. According to S.Chinnamai (2005) "The globalization of higher education can be linked to various changes in the international system. There have been changes in the labor market, which have resulted in calls for more knowledge and skilled workers, and workers with deeper understandings of languages, cultures and business methods all over the world."7 This phenomenon should also be reflected in teachers' education too because there will be a huge requirement of trained teachers by the end of 2030 according to "UNESCO's Institute of Statistics (UNESCO, 2015b) which has estimated that, "globally, 25.8 million extra teachers will need to be recruited by 2030 to meet Education for All (EFA) targets. At present, it is clear that the traditional structures for training teachers cannot keep pace with such expansion" ${ }^{8}$ Now under such huge pressure foreign universities will certainly try to make ways towards India's teacher education as they have entered in technical education of the country. Thus, to remain in competition and to make Indian teachers' education of world level it needs to be restructured based on high quality to meet the needs of global market, so that they may apply the most effective ways of their subject teaching using all available resources. A teacher not only facilitate the student to learn and understand but also mentor him, and to be successful mentor teacher needs to be familiar to the cultural, social and other aspects of that place. Every nation has its own cultural background and traditions. Thus it depicts both the phenomenon i.e. globalization and localization should be considered to restructure our teacher education. Here we can experience two aspects of teachers' training-first is that the cultural identity of trainees should not be ignored by the globalization factor and secondly he should be trained in such a way that he/she may adapt himself to any cultural scenario to serve as international teacher. The trained teachers should be aware of cultural differences and develop the ability to conduce cross-culture communication. We have to realize this vast opportunity in front of our young and trained teachers, which should not be missed by us. No doubt globalization has brought new challenges and requirements on teacher education too, the reform of teaching strategies, target, content and method is an unavoidable task for teacher educators and policy makers for preparing young teachers to more effectively cope with the challenges in the new era. In facing the fast changing environment, many policy makers and educators get confused with uncertainties and ambiguities and lose their directions in the rapid globalization, which has driven numerous educational changes in the different parts of the world. So there is an urgent need of a comprehensive framework for understanding the impacts of rapid developments and advancing implications for innovations in teachers' education. Now the question arises: How teachers' education can be transformed from a traditional country bound training programme to a new globalized teachers' education? According to professor Cheng Yin Cheong of the Hong Kong Institute of Education" This is a challenge of the new global world; graduates from education should not be limited to be technicians or experts in certain areas but also be intelligent leaders and citizens for development of the society in different areas. They have the potential to become contextualized multiple intelligent citizens to creatively and wisely lead the development of the whole society or the global village in facing up challenges in this new century. Borderless education will provide 
innovative ideas and possibilities for restructuring education in different parts of the world to meet the challenges for the future."

The aims of teachers' education should be to develop teachers as leaders and citizens who will creatively contribute to the formation of a global society with multiple developments in technological, economical, social, political, cultural, and learning aspects. One major misunderstanding of challenges of globalization appears to accept it as transfer of knowledge from west to east, while in fact it is not the same. One of the global challenges which are appearing in this context is the vernacular development of any country with all its special cultural identity together with globalization. Only globalization of education is inadequate without localization to pay attention towards the preserving of cultures. It should treat each unique culture and society with due respect, realizing that global education is not only learning about all innovations occurred globally, but also studying different cultures of the world and maintaining them as a cultural heritage of universe. In India the recommendations of "CNR Rao committee set up by ministry of HRD in January 2005 has indicated that government was moving towards a regulatory regime that would permit foreign vercities to set up shops in India in light of GATS. Both favorable and opposing voices heard around to the CNR Rao committee. The Education minister of West Bengal in an Interview to "the Statesman' opposed it by giving a reasons that the syllabi would not reflect Indian culture and ideas merely an alien one and the institutions would be coming to India simply to make money, not to work in the interest of Indian nation."10

In 21st century education system is facing the dual challenge of equipping students with the new knowledge, skills and values needed to be competitive in a global market and producing educated people who are responsible adults, good citizens both of their country and of the world. Thus globalization with localization challenges us to rethink and to restructure teacher education for its ultimate purposes. According to professor Cheng Yin Cheong of Hon Kong Institute of Education "localization refers to the transfer, adaptation and development of related values, knowledge, technology, and behavioral norms from/to the local context." "In software development after a product has been globalized, localization refers to the process of making it ready for a specific market. Similarly globalization and localization of teachers' education is also essential for its balanced development. The main motto for this endeavor should not be the westernization or commercialization of teachers' education. It may not be allowed at the cost of recognition and culture of any locale but with the aim to flourish it worldwide which may only be possible through globalization and localization of teachers' education. In present scenario, NCTE has taken a move towards global perspectives of teacher education by introducing innovative strategies of learning in its curriculum still there is much to be done in the restructuring of teacher education to make our trained teachers able to avail the global opportunities and to become world class and networked teachers through globalization and localization.

\section{Conclusion and suggestions}

Universal fraternity is the principle of ancient Indian culture. Globalization and localization of teacher education is an urgent need so that we may get such teachers who not only will possess world class knowledge but also a global attitude to work and live with open mindedness. In its real sense it will take them forward to the welfare of mankind. The importance of both the phenomenon was predicted by Mahatma Gandhi long before the emergence of these terminologies as quoted by J.L .Azad in his address "I do not want my house to be walled on all sides and my windows to be stuffed. I want the culture of all the lands to be blown about my house as freely as possible, but I refuse to be blown off my feet by any." ${ }^{\prime 2}$ The following suggestions merit serious attention for the development of teacher education at international level. 
- To combat the gap of knowledge worldwide globalization of teacher education is essential.

- The aim of globalization of teachers' education should be to develop such teachers who can face challenges at international level and to develop not only the knowledge aspect of a teacher but a good understanding and goodwill for different nations so that they could transfer the tendencies of co-existence and cooperation in our next generation.

- The misconception of globalization as assuming it to be one way flow from west to east, should be changed through proper educational provisions and understanding.

- As being a service sector Education needs both globalization as well as localization of teachers' education to make it up to date for global and local needs, as the local cultural and social needs should not be ignored in the name of globalization of teacher education.

- Need is to restructure and reform teacher education with reference to globalization and localization both so that cultural identity of trainees should not be ignored by the globalization factor and he should be trained in such a way that he/she may adapt himself to any cultural scenario to serve as international teacher.

\section{References}

1. Azad, J.L.-Globalization and its impact on education (A challenge and an Opportunity) [Ref.

3, 12] Retrieved from https://www.scribd.com/doc/48392155/Globalization-and-its-impact-oneducation

2. Chanda Rupa - GATS and Higher Education in India-an Overview, Dec.2, 2004, pub. June 2, 2005.[Ref.4] Retrieved fromprayatna.typepad.com/education/2005/06/gats_and_higher.html

3. Cheong Cheng- New paradigm of borderless education: Challenges, strategies and implications for effective Education through localization and Internationalization [Ref. 1,9,11] Retrieved from https://home.ied.hk/ yccheng/doc/speeches/14-16oct 02.pdf

4. Chnnammai S.-Effect of globalization on education and culture [Ref 7] Retrieved from https://guidedresearchwriting.pbworks.com/w/file/fetch/53952209/impactofglobalization_edandculture . $\mathrm{pdf}$

5. Moon B. and Villet C. (2016) - Digital Learning: Reforming teacher education to promote access, equality and Quality in Sub-Saharan Africa, published by commonwealth of learning, page no - 06,07 [Ref.6,8] Retrieved from Dspace.col.org/bitstream/handle/1159/2443/2016_Moon_Villet_DigitalLearning-Reforming- Teacher-Education.pdf

6. Rajput J.S. - Planning commission report of Vision 2020. [Ref.5] Retrieved from planningcommission,nic.in/reports/genrep/bkpap2020/14_bg2020.pdf

7. Sharma, R.C. - Population, Resources, Environment and Quality of Life, (1998), Dhanpat Rai and Sons New Delhi. [Ref 2]

8. Soloman A.D., Sanyal B.C., Wildmeersch D. - Engaging with cross-border higher education in India while Sustaining the best tradition of Indian Values [Ref 10] Retrieved from https://www.oecd.org/site/imhe2006bis/37464379.pdf

9 UNESCO: Learning the treasure within- International Commission on Education for $21^{\text {st }}$ Century, Paris 1996. Retrieved from unesdoc.unesco.org/images/0022/002200/220050e.pdf 